\title{
Serological Detection of Antibodies Against Gamma Coronavirus Infection in Scavenging Village Chickens in Ada'a District, Ethiopia
}

\author{
Yonas Tolosa Roba*1, Wabi Bejura ${ }^{1}$, Tsedale Teshome ${ }^{1}$, Asamnew Tesfaye ${ }^{2}$, Naol Mengesha ${ }^{3}$ and \\ Fanos Tadesse Woldemariyam ${ }^{1,4}$ \\ ${ }^{1}$ Addis Ababa University College of Veterinary Medicine and Agriculture, Ethiopia \\ ${ }^{2}$ National Animal Health and Diagnostic Investigation Center (NAHDIC), Ethiopia \\ ${ }^{3}$ Oromia Regional State Livestock Bureau, Ethiopia \\ ${ }^{4} K U$ Leuven, Department of Biosystems, Division of Animal and Human Health Engineering, Laboratory of Host pathogen \\ interaction, Belgium
}

*Corresponding author: Yonas Tolosa Roba, Addis Ababa University College of Veterinary Medicine and Agriculture, Ethiopia

\section{ARTICLE INFO}

Received: 蔧 January 30, 2021

Published: 㥃 February 08, 2021

Citation: Yonas Tolosa Roba, Wabi Bejura, Tsedale Teshome, Asamnew Tesfaye, Naol Mengesha, Fanos Tadesse Woldemariyam. Serological Detection of Antibodies Against Gamma Coronavirus Infection in Scavenging Village Chickens in Ada'a District, Ethiopia. Biomed J Sci \& Tech Res 33(4)-2021. BJSTR. MS.ID.005448.

Abbreviations: IBV: Infectious Bronchitis Virus; PA: Peasant Associations; N: Nucleocapsid Protein; E: Small Envelope Protein; M: Membrane Glycoprotein; S: Spike Glycoprotein; NAHDIC: National Health Diagnosis and Investigation Center; ELISA: Enzyme Linked Immunosorbent Assay

\begin{abstract}
Infectious bronchitis virus (IBV) is a highly contagious disease of birds causing significant economic losses globally. Unvaccinated scavenging chicken may serve as a source of infection for the commercial poultry farms and hence controlling the disease relying only on vaccinating commercial flocks resulted in poor achievement. The objective of this study was to determine the prevalence of IB among village chickens scavenging in Ada'a district, Ethiopia. The study area was selected for the fact that most of the commercial farms are present and thus characterized by a high density of poultry breeding. Eleven peasant associations (PA) from a total of 22 Ada'a districts were selected purposefully considering their close proximity to the large commercial poultry farms. The study was conducted on a total of 426 adult unvaccinated scavenging village chickens and sera were analyzed by an indirect ELISA test. The overall seroprevalence found in this particular study was $64.79 \%$. Among the villages, the highest seroprevalence of IBV was detected at Yatu and Kality villages reaching up to $93.9 \%$ and $92.3 \%$ and mean antibody titer of 7097.32 and 8942.95 respectively. Given the high prevalence observed in the study area suggests an urgent need for the development of preventive and control strategies against IB not only for commercial farms but also it should consider the scavenging chicken for better achievement.
\end{abstract}

Keywords: Ada'a; IB; Scavenging; Chicken; Serology

\section{Introduction}

The total chicken population in Ethiopia is estimated to be 56.5 million with native chicken representing 96.9\%, hybrid chicken $0.54 \%$ and exotic breeds $2.56 \%$ [1]. The most dominant chicken types reared in Ethiopia are local ecotypes, which show a large variation in body position, plumage color, comb type and productivity [2]. However, the economic contribution of the sector is not still proportional to the huge chicken numbers, attributed to the presence of many productions, reproduction and infrastructural constraints [3]. The indigenous flocks are said to be disease resistant and adapted to their environment. However, the survival rates of the Ethiopian indigenous chicks kept under natural brooding conditions considered low. Disease and predators are known to be the major causes of mortality in the country [4,5]. According to Negussie, et al. [6], Newcastle disease accounted for the largest 
proportion of overall flock mortality to be $57.3 \%$ followed by fowl pox $31.6 \%$, coccidiosis, $9.4 \%$ and predator loss $1.7 \%$. Another study conducted in all zones found in Southern Ethiopia by Aberra, et al. [7] indicated that the major problems of poultry production in the study were Fowl cholera (28.8\%), followed by Newcastle disease (26\%), coccidiosis 921.6\%), Fowl influenza (15.4\%), fowl pox (3.4\%), fowl typhoid (3.4\%), and salmonellosis (1.4\%) [8].

Infectious bronchitis (IB) is a highly contagious disease of birds, caused by Infectious bronchitis virus enveloped, positive-sense, and single-stranded RNA virus, belonging to the genus: Gamma coronavirus, family coronaviridae $[9,10]$. The genome of the virus is approximately $27.6 \mathrm{~kb}$ in size encoding 4 structure proteins namely phosphorylated nucleocapsid $(\mathrm{N})$ protein, small envelope protein (E), integral membrane glycoprotein (M), and spike glycoprotein (S) in the order of $5^{\prime}$-Pol-S-3a-3b-E-M-5a-5b-N-UTR3' [11]. The hypervariable regions have the characteristic of virus neutralization and serotype-specific antigenic determinants responsible for binding to the host cell, neutralization, and immune response [12] and responsible for the pathogenicity of the virus to the host cell [13]. The virus is highly contagious and causes upper respiratory disease in chickens [14] with significant economic losses globally [15]. In hens, it also results in reduction of egg production and poor egg quality. Interstitial nephritis and mortality is also often observed in some strains of the virus [16]. All ages groups can be affected by the disease [17] among which extremely susceptible are chicks of 2 to 3 weeks of age. The overall mortality rates reaches as high as $40 \%-90 \%$ in affected chicks [18]. The disease is transmitted through the air-borne, mechanical transmission between birds, houses, and farms [19] and control of IB is essentially based on the use of live attenuated and killed vaccines. However, the low level of cross protection between vaccines of different serotypes is a major obstacle to IB control (Cavanagh and Naqi, 2003). Moreover, scavenging chicken may serve as a source of infection for the commercial poultry farms and hence controlling the disease only by vaccination makes it more difficult. Therefore, the effects of this disease have been a problem to the poultry sector in Ethiopia in particular and worldwide in general. The objective of the study was to determine the prevalence of infectious bronchitis virus among scavenging village chickens in central Ethiopia using an ELISA assay. The study focused on Ada'a district, areas surrounding Bishoftu, a city where most of the commercial farms present and thus characterized by a high density of poultry breeding.

\section{Materials and Methods}

\section{Study Area}

The study was conducted from December 2018 to April 2019 in villages found in Ada'a district of Bishoftu city. The Ada'a district has a total of 22 peasant associations (PAs). Bishoftu is also home to the country's main commercial poultry farms. The area is located at $9{ }^{\circ} \mathrm{N}$ latitude and $40^{\circ} \mathrm{E}$ longitudes at an altitude of 1850 meters above sea level in central high land of Ethiopia. It has an annual rainfall of $866 \mathrm{~mm}$ of which $84 \%$ is in the long rainy season (June to September). The dry season extends from October to February. The mean annual maximum and minimum temperatures are $26{ }^{\circ} \mathrm{C}$ and $14{ }^{\circ} \mathrm{C}$ respectively, with mean relative humidity of $61.3 \%$ [20].

\section{Study Design and Sample Size}

Cross-sectional study was conducted on 11 PAs' that were purposefully selected from the total of 24 PAs' considering their geographical location and closeness to the large commercial poultry farms. Hence, a total number of 426 backyard-scavenging chickens were randomly sampled. The sample size was determined using the formula given by Thrusfield (2005). As there was no previous estimated prevalence of IB in scavenging village chickens, $50 \%$ was considered as expected prevalence and desired absolute precision of $5 \%$ at $95 \%$ confidence level. Thus, the minimum overall sample size required for the study was 384. However, to increase the precision a total of 426 scavenging village chickens were included in this study.

\section{Blood Sampling and Storage}

Blood samples were collected from a total of 426 adult unvaccinated scavenging chickens through venipuncture (wing) using $2 \mathrm{ml}$ syringe and 24 gauge size hypodermic needle and then transferred into labeled plain vacutainer tubes. The samples were transported immediately after collection to the college of veterinary medicine and agriculture of Addis Ababa University in icebox and kept at room temperature to clot. After decanting the serum into cryovial, it was temporary stored at $-20^{\circ} \mathrm{C}$ and finally the sera were kept in icebox with icepack and transported to the National Health Diagnosis and Investigation Center (NAHDIC) for serological test using ELISA.

\section{Serological Analysis}

Serological tests were used in epidemiological studies for IBV detection. The sera were analyzed by an indirect ELISA test (IDEXX infectious bronchitis virus antibody test, IDEXX®, US). The test is designed to detect IBV specific antibodies conserved between different serotypes, which promote the detection of all IBV types. The test consisted of five 96 well plates (pre-coated with a purified viral antigen), positive and negative IBV antibody control sera $(1.9 \mathrm{~mL})$, conjugate $(50 \mathrm{~mL})$, sample diluent $(235 \mathrm{~mL}), \mathrm{TMB}$ substrate $\left(3,3^{\prime}, 5,5^{\prime}\right.$-Tetramethylbenzidine) $(60 \mathrm{~mL})$ stop solution $(60 \mathrm{~mL})$. Each serum sample was singly tested for IBV antibodies using the enzyme linked immunosorbent assay (ELISA) technique. Prior to being assayed, a 1:500 dilution of the samples was made with manufacturer's diluent in a 2-step process. $100 \mu \mathrm{l}$ of each diluted sample was then pipetted into the appropriate well on the antigen-coated plate. One hundred microliters of undiluted positive and negative controls was added to their appropriate wells in duplicate. Thenceforth, the plate was incubated for $30 \mathrm{~min}$ at room temperature. Plates were then manually washed five times with deionized water and blotted dry on laboratory tissue paper after 
washing. Hundred microliters of conjugate was added to all wells and the plate was incubated at room temperature for $30 \pm 2 \mathrm{~min}$. Washing and blotting were repeated as described above. One hundred microliters of TMB substrate was added to all wells and incubated at room temperature for $15 \pm 1 \mathrm{~min}$. To stop the reaction, $100 \mu \mathrm{l}$ of stop solution was added to all the wells. The micro plates were analyzed by the ELISA microplate reader (MACHINE MARK®), at a wavelength of $650 \mathrm{~nm}$.

\section{Data Analysis}

The optical density (OD) values were transferred onto an excel worksheet. The Positive Control Means (PCX) and Negative Control Means (NCX) for each test plate were calculated (Microsoft Excel, Microsoft Office 15). An assay was accepted to be valid when the NCX absorbance was less than or equal to 0.150 and the difference between PCX and NCX was greater than 0.075.The formula used for the calculation was the following: $\mathrm{S} / \mathrm{P}=$ sample (OD)-NCX(OD)/ PCX(OD)-NCX(OD), Where S/P is sample to positive ratio, Sample (OD) is OD of test serum, NCX (OD) is mean OD of negative control, and PCX (OD) is mean OD of positive control. The test was valid if the difference between the average value of the positive controls and the average value of the negative controls is greater than 0.075 and the mean value of negative controls is less than 0.150 . The interpretation of the results was determined by the ELISA sample to positive ratio for each serum. The threshold of positivity was fixed at 0.20 (antibody titer $=396$ ). The samples with $\mathrm{S} / \mathrm{P}<0.20$ (antibody less or equal to 396) were negative, whereas samples with $\mathrm{S} / \mathrm{P}>0.20$ (antibody titer higher than 396) were considered positive. IBV prevalence was calculated as the percentage of positive sera among the total number of analyzed sera. The average titer of antibodies was also calculated and compared with the positivity threshold of the test according to [21] IBV antibody titer was classified as low (titer level ranging from 397-1000), medium (1001-5000) or high (titers $>5000$ ). The overall district and peasant association level of prevalence was calculated using descriptive statistics.

\section{Results}

In the present study, the test carried out on a total of 426 adult unvaccinated scavenging chickens sera from different villages in Ada'a district for infectious bronchitis virus (IBV) prevalence. Hence an overall seroprevalence of 64.79 (Table 1) was recorded in the district. Computing this over all prevalence of each village gives highest seroprevalence 10.8, 9.15 and 8.45 percent of the disease in Yatu ,Giche and kality PAs respectively where as Wajitu and Denkaka had the lowest percentage of prevalence (1.88). The remaining PAs falls in the range of the mentioned numbers (Table 1). Similarly the seroprevalence in scavenging chickens within the villages was also computed and highest prevalence of IBV was detected at Yatu PA with $93.9 \%$ and mean antibody titer of 7097.32 followed by Kality PA with $92.3 \%$ of prevalence but with the highest mean antibody titer of 8942.95 . On the other hand lowest prevalence of $44.26 \%$ and $17.64 \%$ was recorded in Cheleba Silase and Denkaka PAs with mean antibody titer of 1251.43 and 1693.14 respectively (Table 2).

Table 1: Overall prevalence of infectious bronchitis (IB) in scavenging chickens in the study 290 villages.

\begin{tabular}{|c|c|c|c|}
\hline $\begin{array}{c}\text { Peasant } \\
\text { Associations } \\
\text { (PA) }\end{array}$ & $\begin{array}{c}\text { Number of Samples } \\
\text { Collected }\end{array}$ & $\begin{array}{c}\text { No. of Positives } \\
\text { from the Total } \\
\text { Samples }\end{array}$ & $\begin{array}{c}\text { Overall } \\
\text { Prevalence } \\
\text { (\%) }\end{array}$ \\
\hline Kality & 39 & 36 & 8.45 \\
\hline Godino & 29 & 21 & 4.93 \\
\hline Bekejo & 44 & 31 & 7.28 \\
\hline Denkaka & 47 & 8 & 1.88 \\
\hline Ude & 31 & 25 & 5.87 \\
\hline Golodertiu & 40 & 27 & 6.34 \\
\hline Chelabasilase & 51 & 23 & 5.4 \\
\hline Wajitu & 12 & 8 & 1.88 \\
\hline Yatu & 49 & 46 & 10.8 \\
\hline Giche & 59 & 39 & 9.15 \\
\hline Hidi & 25 & 12 & 2.82 \\
\hline
\end{tabular}

Table 2: Prevalence of infectious bronchitis virus among scavenging chickens in different 296 peasant associations.

\begin{tabular}{|c|c|c|c|}
\hline $\begin{array}{c}\text { Peasant } \\
\text { Associations } \\
\text { (PA) }\end{array}$ & $\begin{array}{c}\text { Number of } \\
\text { Samples/Total No. } \\
\text { of Population }\end{array}$ & $\begin{array}{c}\text { No. of Positives } \\
\text { from the Total } \\
\text { Samples }\end{array}$ & $\begin{array}{c}\text { Prevalence } \\
\text { (\%) }\end{array}$ \\
\hline Kality & $39 / 5400$ & 36 & 92.3 \\
\hline Godino & $29 / 5500$ & 21 & 72.41 \\
\hline Bekejo & $44 / 4740$ & 31 & 70.45 \\
\hline Denkaka & $47 / 6500$ & 8 & 17.02 \\
\hline Ude & $31 / 4500$ & 25 & 80.64 \\
\hline Golodertiu & $40 / 3347$ & 27 & 67.5 \\
\hline Chelabasilase & $51 / 4340$ & 23 & 45.09 \\
\hline Wajitu & $12 / 3702$ & 8 & 66.6 \\
\hline Yatu & $49 / 2330$ & 46 & 93.88 \\
\hline Giche & $59 / 5294$ & 39 & 66.1 \\
\hline Hidi & $25 / 5400$ & 12 & 48 \\
\hline
\end{tabular}

\section{Discussion}

The overall prevalence of IB in backyard-scavenging chickens in the study was 64.79 showing a high prevalence rate of the disease in the area and even reaching as high over as $90 \%$ in some of the PAs. A relatively low prevalence was registered in Denkaka PA (17.64\%). This difference in prevalence rate among the PA in the study area might be due to their geographical locations in relation to the commercial farms and the less movement of chickens (no live poultry market). This low prevalence registered at Denkaka PA (17.64) is in harmony with the study conducted by [22] who reported that IB is less prevalent at a rate of $18.8 \%$ in village chickens of Maiduguri, Nigeria and [23] who reported that IBV is less common in northern Nigeria and in backyard poultry in Niger Republic. Unexpectedly, in the present study in most of the villages, 
a high prevalence rate of IB was seen where generally expected to be disclosed by intensive poultry farms. The high prevalence rate scored at Yatu (93.9\%) and Gote (92.3\%) are in agreement with the reports from commercial poultry farms from Ethiopia (94.5\%) by Hutton, et al. [24], Jordan (92.9\%) by Rousson, et al. [25], Kano, Nigeria (91.3\%) by Oyejide, et al. [26] and in Pakistan (88\%) by Ahmad, et al. [27]. Moreover, the seroprevalence observed in other villages of the study area are very close to reports from commercial poultry farms in Nigeria (84\%), Ghana (85.5\%), Sudan (71\%) and south west of Nigeria (84.98\%). The mean titer of IBV observed in the present study is 3250.58, significantly (8 times) higher than the threshold (396) reported for negative samples. This titer is considered as medium titer, between low titers (1001) and high titers (5000), because it was observed in industrial chicken flocks. However, Hadipour, et al. [28] indicated that an antibody titer of 1427 was considered as high, because their serological study was conducted on endogenous chicken.

To sum up, the unvaccinated status of the backyard-scavenging chickens in this study would indicate a natural infection with a potentially high virulence strain of IBV. Even if Ethiopia's over 95\% of the poultry population is reared under extensive production management system (scavenging), vaccination of these chickens against any poultry diseases is not practiced. The country's current poultry disease prevention strategy is fully targeting the commercial farms. However, this practice encourages easy spread of infectious agents and backyard chickens can also serve as a reservoir for infectious agents [29]. Given the high prevalence observed in the study area suggests an urgent need for the development of preventive and control strategies against IB not only targeting for the commercial farms but also in consideration of the scavenging chickens for a better achievement. We recommend isolation and serotyping of IBV from the study area as a future study.

\section{Acknowledgement}

The National Animal Health Diagnostic and Investigation Center and the Addis Ababa University supported this work.

\section{Conflict of Interest}

The authors declare that they have no competing interests.

\section{References}

1. (2017) CSA. Federal democratic republic of Ethiopia: Agricultural sample survey: Report on livestock and livestock characteristics private peasant holdings. Stat bulletin 585 April 2017, Ethiopia.

2. Halima HM (2007) Phenotypic and genetic characterization of indigenous chicken populations in Northwest Ethiopia. Ph.D. Thesis, University of Free State, Bloemfontein, South Africa.

3. Aberra M (2000) Comparative studies on performance and physiological responses of Ethiopian indigenous (Angete-Melata) chickens and their f1 crosses to long-term heat exposure. CAB Direct: pp. 145.

4. Hoyle E (1992) Small-scale poultry keeping in Welaita, North Omo region. Technical pump blet No. 3 Farmers Research Project (FRP). Farm Africa Addis Ababa.
5. Negussie D (1999) Evaluation of the performance of local Rhode Island Red (RIR) and Fayoumi breeds of chicken under different management regimes in the high lands of Ethiopia. Swedish University of agricultural sciences, Department of animal nutrition and management. Trop Anim Health Pro 33: 521-537.

6. Negussie D, Ogle B (1999) On farm evaluation of Rhode Island Red (RIR) and local chickens under different management regimes in the high land of Ethiopia Swedish university of agricultural science department of animal nutrition and management. M.Sc. Thesis, Uppsala Sweden.

7. Aberra M, Tegene N (2007) Study on the characterization of local chicken in Southern Ethiopia. Proceedings held in Hawassa, Ethiopia.

8. Mekonnen G (2007) Characterization of smallholder poultry production and marketing system of dale, wonsho and lokaabayaworedas of southern Ethiopia. MSc Thesis. Hawassa University.

9. Cavanagh D, Naqi SA (2003) Infectious Bronchitis. In: Saif YM, Barnes HJ, Glisson JR, Fadly AM, McDougald LR, et al. (Eds.)) Diseases of Poultry. (11 ${ }^{\text {th }}$ Edn.)., Wiley, New York, USA, pp. 101-119.

10. Casais R, Thiel V, Siddell SG, Cavanagh D, Britton P (2001) Reverse genetics system for the avian coronavirus infectious bronchitis virus. J Virol 75(24): 1235-1239.

11. Umar S, Shah M, Munir M, Ahsan U, Kaboudi K (2016) Infectious bronchitis virus: evolution and vaccination. Worlds Poult Sci J 72(1): 49-60.

12. Johnson MA, Pooley C, Ignjatovic J, Tyack SG (2003) A recombinant fowl adenovirus expressing the $\mathrm{S} 1$ gene of infectious bronchitis virus protects against challenge with infectious bronchitis virus. Vaccine 21: $2730-2736$.

13. Zeng F, Hon CC, Yip CW, Law KM, Yeung YS, et al. (2006) Quantitative comparison of the efficiency of antibodies against S1 and S2 subunit of SARS coronavirus spike protein in virus neutralization and blocking of receptor binding: Implications for the functional roles of S2 subunit. FEBS Lett 580(24): 5612-5620.

14. Liu S, Chen J, Kong X, Shao Y, Han Z, et al. (2005) Isolation of avian infectious bronchitis coronavirus from domestic peafowl (Pavocristatus) and teal (Anas). J Gen Virol 86(3): 719-725.

15. Cook JKA, Jackwood M, Jones RC (2012) The Long View: 40 Years of Infectious Bronchitis Research. Avian Pathol 41(3): 239-250.

16. Office International Épizooties (2008) Health standard: avian infectious bronchitis Manual of diagnostic tests and vaccines for terrestrial animals.

17. Britton P, Cavanagh D (2007) Avian coronavirus diseases and infectious bronchitis vaccine development: Coronavirus molecular and cellular Biology. Caister Academic Press pp. 161-181.

18. Javed T, Siddique M, Hameed A (1991) Persistence and morphopathological studies on infectious bronchitis in chickens in Pakistan. Assiut Vet Med J 49: 216-228.

19. Cavanagha D, Gelb Jr J (2008) Infectious Bronchitis. In: Saif YM, Fadly AM, Glisson JR, McDougald LR, Nolan LK, et al. (Eds.).)., Diseases of Poultry (12 ${ }^{\text {th }}$ Edn.,), Blackwell Publishing Professional, Ames, Iowa, USA: 978-0-8138-0718-8: 117-135.

20.ADARDO (2007) Ada'a District Agricultural and Rural Development Office.

21. Ayim Akonor M, Obiri Danso K, Toah Akonor P, Sellers HS (2018) Widespread exposure to infectious bronchitis virus and Mycoplasma gallisepticum in chickens in the East district of Accra, Ghana. Cogent Food Agric 4(1).

22. Shettima YM, El Yuguda AD, Zanna MY, Abubakar MB, Hamisu TM (2016) Serological evidence of infectious bronchitis virus among some poultry species in Maiduguri, Nigeria. Alexandria J Vet Sci 51(1): 135-139.

23. Ducatez MF, Martin AM, Owoade AA, Olatoye IO, Alkali BR (2009) Characterization of a new genotype and serotype of infectious bronchitis virus in Western Africa J Gen Virol 90(11): 26792685. 
24. Hutton S, Bettridge J, Christley R, Habte T, Ganapathy K (2017) Detection of infectious bronchitis virus 793B, avian metapneumovirus, Mycoplasma gallisepticum and Mycoplasma synoviae in poultry in Ethiopia. Trop Anim Health Prod 49(2): 317-322.

25. Roussan DA, Khawaldeh GY, Shaheen IA (2009) Infectious bronchitis virus in Jordanian chickens: Seroprevalence and detection. Can Vet J 50(1): 77-80

26. Oyejide A, Demangam VL, Akinyemi JO (1988) Serological survey of antibodies to Infectious bronchitis in commercial and indigenous Nigerian chickens using ELISA. Bull. Anim Health Prod Afr 3: 259-262.

ISSN: 2574-1241

DOI: 10.26717/BJSTR.2021.33.005448

Yonas Tolosa Roba. Biomed J Sci \& Tech Res

(C) (i) This work is licensed under Creative

Submission Link: https://biomedres.us/submit-manuscript.php
27. Ahmed Z, Naeem K, Hameed A (2007) Detection and seroprevalence of infectious bronchitis virus strains in commercial poultry in Pakistan. Poult Sci 86(7): 1329-1335.

28. Hadipour MM, Azad F, Vosoughi A, Fakhrabadipour M, Olyaie A, et al. (2011) Measurement of antibodies to infectious bronchitis virus in indigenous chicken flocks around Maharlou Lake in Iran. Int J Anim Vet Adv 3(3): 182-185.

29. Gueye EF (2007) Evaluation of the impact of HPAI on family poultry production in Africa. World Poult Sci J 63(3): 391-399.

$\begin{array}{ll}\text { BIOMEDICAL } & \text { Assets of Publishing with us } \\ \text { RESEARCHES } & \text { - Global archiving of articles } \\ \text { - Immediate, unrestricted online access } & \text { - Rigorous Peer Review Process } \\ & \text { - Authors Retain Copyrights } \\ \end{array}$

